\title{
Data Report: "Health care of Persons Deprived of Liberty" Course From Brazil's Unified Health System Virtual Learning Environment
}

\begin{abstract}
Janaína Valentim ${ }^{1,2 \star}$, Eloiza da S. G. Oliveira ${ }^{1,3}$, Ricardo A. de M. Valentim ${ }^{1}$, Sara Dias-Trindade ${ }^{4}$, Aline de Pinho Dias ${ }^{1}$, Aliete Cunha-Oliveira ${ }^{2,5}$, Ingridy Barbalho ${ }^{1}$, Felipe Fernandes ${ }^{1}$, Rodrigo Dantas da Silva ${ }^{1}$, Manoel Honorio Romão ${ }^{1}$, César Teixeira ${ }^{6}$ and Jorge Henriques ${ }^{6}$

${ }^{1}$ Laboratory of Technological Innovation in Health, Federal University of Rio Grande Do Norte, Natal, Brazil, ${ }^{2}$ Univ Coimbra, Centre for Interdisciplinary Studies of the 20th Century, Coimbra, Portugal, ${ }^{3}$ Multidisciplinary Institute for Human Development With Technologies, State University of Rio de Janeiro (UERJ), Rio de Janeiro, Brazil, ${ }^{4}$ Univ Coimbra, Centre for Interdisciplinary Studies of the 20th Century (CEIS20), Faculty of Arts and Humanities (DHEEAA), Coimbra, Portugal, ${ }^{5}$ Health Sciences Research Unit: Nursing (UICISA: E), School of Nursing of Coimbra (ESEnfC), Coimbra, Portugal, ${ }^{6}$ Univ Coimbra, Centre for Informatics and Systems of the University of Coimbra, Department of Informatics Engineering, Coimbra, Portugal
\end{abstract}

Keywords: sexually transmitted infections, persons deprived of liberty, prisional system, education, SUS-Brazilian national health system

Zaleha Abdullah Mahdy,

Edited by: National University of Malaysia,

Malaysia

Reviewed by:

Daniel Rainkie,

Qatar University, Qatar

Seng Fah Tong

National University of Malaysia,

Malaysia

*Correspondence:

Janaina Valentim

janaina.Irsv@lais.huol.ufrn.br

Specialty section:

This article was submitted to Healthcare Professions Education,

a section of the journal

Frontiers in Medicine

Received: 15 July 2021 Accepted: 25 August 2021 Published: 20 September 2021

Citation:

Valentim J, Oliveira EdSG, Valentim RAdM, Dias-Trindade $S$,

Dias AdP, Cunha-Oliveira A Barbalho I, Fernandes F, Silva RDd,

Romão $\mathrm{MH}$, Teixeira $\mathrm{C}$ and

Henriques J (2021) Data Report: "Health care of Persons Deprived of Liberty" Course From Brazil's Unified

Health System Virtual Learning Environment. Front. Med. 8:742071. doi: 10.3389/fmed.2021.742071

\section{INTRODUCTION}

The Brazilian prison system has a history of shortcomings related to lack of investments and infrastructure, leading to severe consequences for the entire prison population, such as problems related to fundamental guarantees of human rights, the lack of health care, and the rise in criminality rates (1-3). With almost the third-largest prison population (4), Brazil accumulates critical issues such as overcrowding, high internal violence indexes, and disease spread (5-7). Data from January to June 2019, from the National Survey of the Penitentiary Information System (Infopen) - Brazil's system of statistical information regarding correctional facilities, published by the National Penitentiary Department (8) - pointed out that the Brazilian prison population was 752,277. Thus, 31,742 people had some condition, 8,523 were HIV-positive, 6,920 had syphilis, 9,113 had tuberculosis, and 7,186 had other diseases.

We present a set of factors that characterize the population deprived of liberty as a vulnerable group to Sexually Transmitted Infections (STIs) (9). Among those that most affect this highly invisible population, Syphilis, HIV, and Tuberculosis are most prominent due to their fast spread and the challenges for diagnosing and accessing treatment (10-12). Yet, in this discouraging spectrum, hope still lingers. It is represented by public policies that genuinely serve such a population and human education aiming to develop its potential fully, including individuals who permeate the prison system in its totality, both those deprived of their liberty and professionals who work there.

Brazilian Prison System, we find such diseases, as mentioned above, quite often. Nevertheless, we believe this scenario can be changed. We believe in a scenario where those conditions can be efficiently avoided and their dissemination rate reduced. We consider that the development of educational resources is a strategy toward human education in health, both for professionals and the community in general. Our investment in education and training strategies is based on studies that indicate the need for educational measures to prevent and promote health care for people deprived of their liberty $(13,14)$. Taking into account that, besides the high prevalence of these infections in the prison system, we also face knowledge deficits on the subject, misperceptions, and peculiar conditions of imprisonment, which result in at-risk behaviors. 
At the core of our observation, the first problem question arises: can a technology-based educational activity train professionals for syphilis and other STIs demands within the prison system? As an answer, we have established the first goal: constructing a data report through an object that combines the two previously mentioned strategies. Thus, (1) a public policy that emphasizes the Virtual Learning Environment of the Unified Health System (AVASUS, in Portuguese: Ambiente Virtual de Aprendizagem do Sistema Único de Saúde) and (2) the course on "Health care of Persons Deprived of Liberty" (15). AVASUS is a virtual learning space for healthcare professionals, students, and general society to enhance SUS training, management, and care. As for the course "Health care of Persons Deprived of Liberty" (ASPPL, in Portuguese: Atenção à Saúde da Pessoa Privada de Liberdade), its learning objectives are characterizing the prison population and introducing the central public policies aimed at this population, with substantial reflections for primary care practitioners. Together, these two resources develop skills that allow for comprehensive care for the person deprived of liberty.

Based on universality, equity and integrity, the ASPPL selfinstructional course encompasses the legal and historical contexts of health care of the Brazilian prison population. Its 30-h workload is organized into four units. It focuses on the national prison assistance scenario, the main problems, and specific needs that affect incarcerated people, and the attributions of the Family Health Strategy team-ESF, in Portuguese: Estratégia de Saúde da Família-as to the welcoming and care of people deprived of liberty. The course methodology is based on a proposal of active learning through Problem-Based Learning, simulating real-life situations to stimulate the student's motivation to search for solutions as a starting point for acquiring and integrating new knowledge. In addition to problems, several resources are used, such as texts, animations, interactive timelines, infographics, videos, and games. Thus, it presents a training structure for health professionals to get to know and work in the Brazilian prison system and for the general population to get acquainted with the reality of the penitentiary system, chiefly actions developed in this context.

With the perspective of providing the appropriate content for health professionals and the general population, the course syllabus was produced by a team composed of experts in the field of knowledge and with great practical experience, selected through public notice and submitted to training specific. In the production process, the course was subjected to moments of quality assessment: (a) Technical-scientific assessment; (b) Pedagogical assessment; (c) Brazilian Association of Technical Standards (ABNT, in Portuguese: Associação Brasileira de Normas Técnicas) assessment (standardization) and Portuguese language; (d) Instructional design assessment; (e) Communication assessment; (f) Final evaluation of content writer. AVASUS' pedagogical team accompanies the content writer throughout the course's preparation process until its completion and availability on the platform, ensuring the balance of educational content for access by the target audience.

Then, a second question emerges: with the data of this course participants, is it feasible to measure or map trained professionals for the healthcare demands in the Brazilian prison system in Brazil? The data report we present to answer such question purposes to perform a descriptive analysis of ASPPL's data and provide a repository containing the set of participants' data so that the scientific community may contribute with further research. This repository contributes to the definition of scenarios that enable assessing the quality of health care in the Brazilian prison system and visualizing essential characteristics, such as profile and geographic location, related to the participants who took the course and to the health care facilities. In addition, it allows crossover with epidemiological data on STIs, enabling the analysis of the subject's causal relationship. Finally, the study of this dataset can also help adopt preventive measures that consequently contribute to a decrease in the transmission rate of STIs.

\section{MATERIALS AND METHODS}

\subsection{Data Acquisition}

The original data of the ASPPL course participants were extracted from AVASUS (15). Since course enrollment is continuously available, data collection comprises from the course's start date to the day of data collection, $06 / 07 / 2018$ to $05 / 25 / 2021$, respectively. Initially, the dataset is composed of 14 attributes and 4,861 instances. The attributes, except the unique identifier of the instances (id), correspond to the personal information of the course participants. These are as follows: gender; Brazilian Occupational Classification (CBO, in Portuguese: Classificação Brasileira de Ocupações); participant's occupation through $\mathrm{CBO}$; occupation declared by the participant; course completion percentage; evaluation of the course in free text and on a satisfaction level scale ranging from 1 to 5; geographic location (Municipality and State); employment relationship(s); type(s) of health establishment(s), and whether these are linked or not to the prison system. Attribute types vary, i.e., they are multivalued, and 11 of them have missing values.

\subsection{Data Processing}

Original data was pre-processed through the pipeline described below. In addition, an organized version of the dataset suitable for exploratory data analysis by the scientific community was created. The executed pipeline for data processing, supported by the Python programming language and classical libraries from the data science field, is composed of the following steps: (i) data retrieval and standardization; (ii) treatment of missing data; (iii) data transformation; and (iv) feature selection. The new dataset, formatted as a comma-separated values (.csv) file named "asppl-dataset.csv," comprises 33 attributes and 4,861 instances. A detailed description of the dataset is available for public consultation at the repository (available at: https://zenodo.org/ record/5095518\#.YO3gshNueLo).

In the pipeline's first stage, data recovery and standardization (i), work focused on the recovery of missing data on the "gender" and type(s) of health establishment(s) attributes. In the original dataset, $36.65 \%(1,782)$ of the instances did not have values referring to participants' gender. After consulting the database of the Permanent Integration System of Education Strategies of the Ministry of Health of Brazil, Sabiá, developed by LAIS/UFRN, 
A

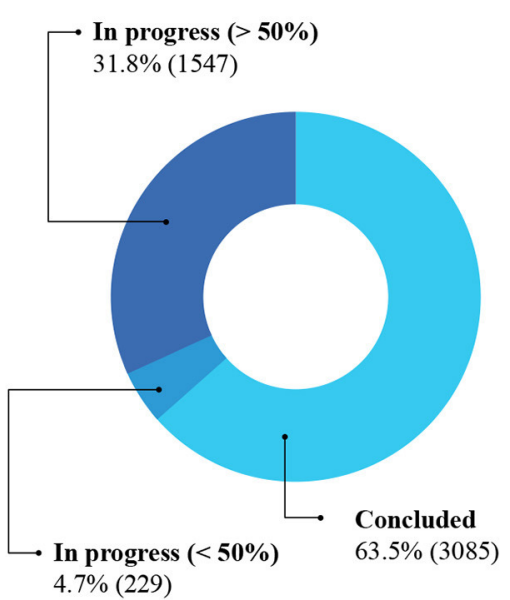

B

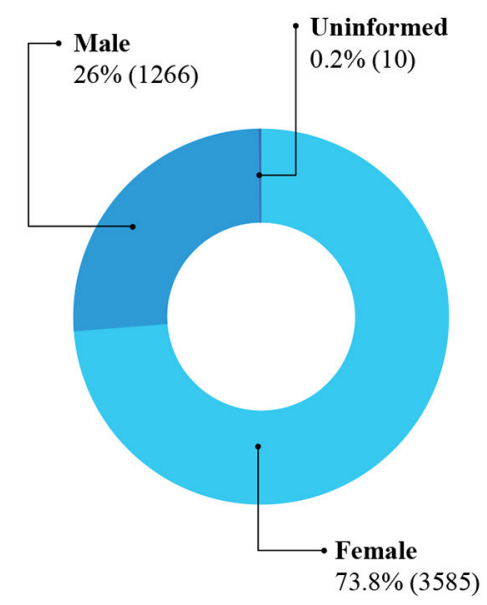

C

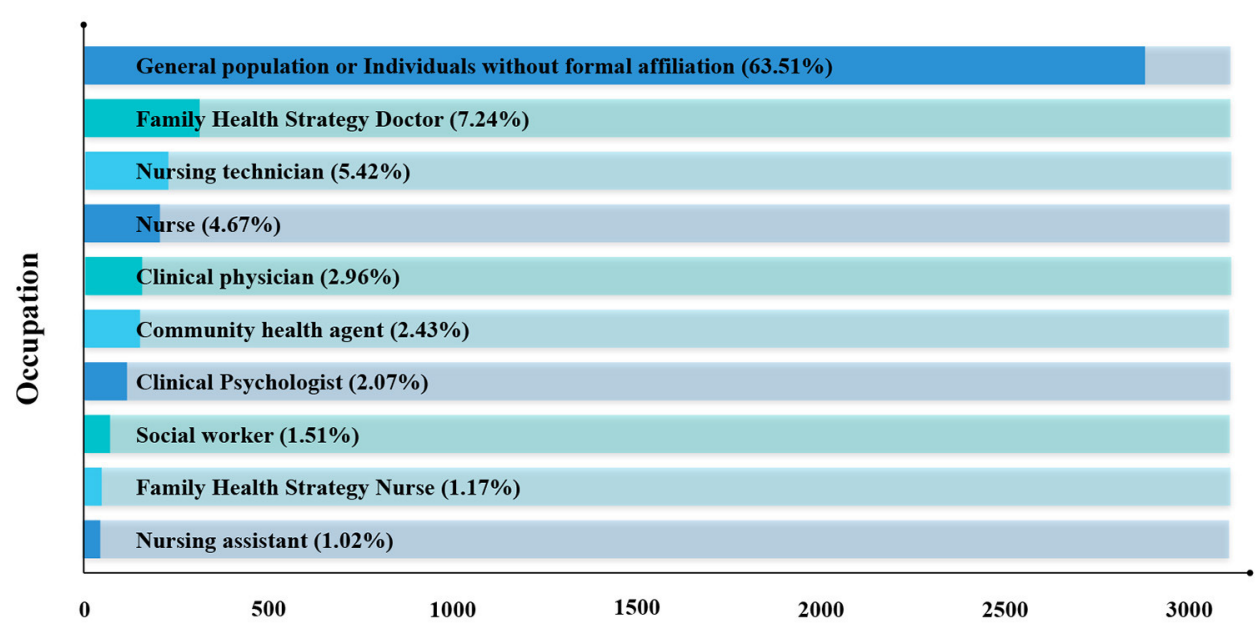

D

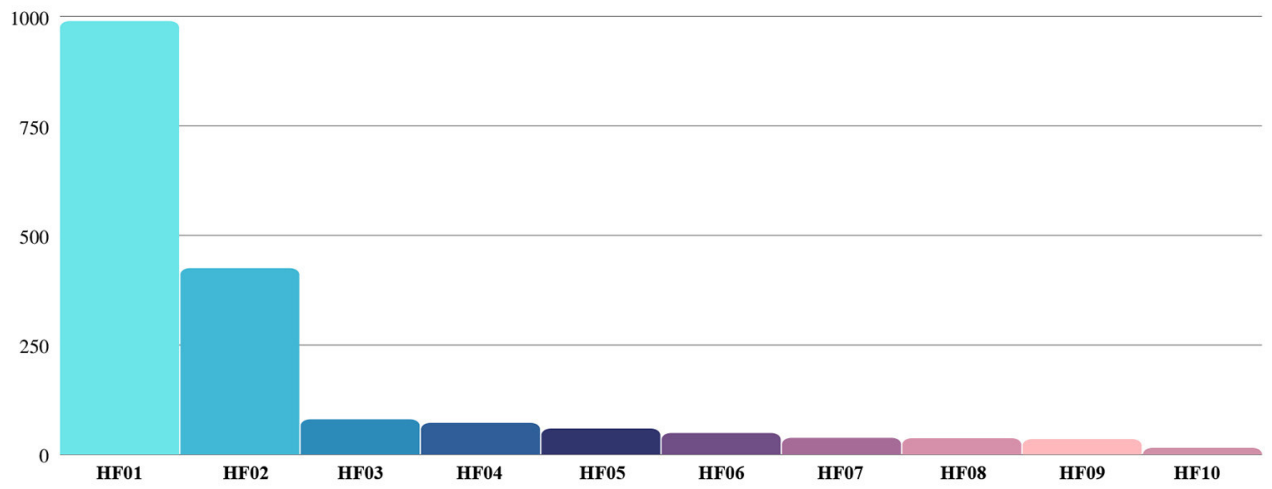

FIGURE 1 | "asppl-dataset.csv" analysis of repository data. (A) Number of participants who completed the course. (B) Number of participants by Gender. (C) Number of occupations of the participants. (D) Number of health facilities where participants work. HF01, Health Center/Primary Unit; HF02, General Hospital; HF03, Specialty Clinic/Center; HF04, Health Center; HF05, Health Management Center; HF06, Specialized hospital; HF07, Prompt service; HF08, Polyclinic; HF09, Psychosocial care center; HF10, Isolated office. 
approximately $99.44 \%(1,772)$ of missing data on the "sex" attribute were retrieved. Continued the recovery process, the instances of the attribute "type(s) of work establishment(s)" to which there was no relevant data were $61.16 \%$ retrieved through the National Registry of Health Establishments (CNES, in Portuguese: Cadastro Nacional de Estabelecimentos de Saúde) (16). In standardization, data conventions were created for the following attributes: gender, CBO, State, and employment(s).

For handling the missing data (step ii), missing values of the gender, $\mathrm{CBO}$, and region attributes (see step iii) were replaced. For missing data values of the gender attribute, the term "Not Informed" was assigned, as it was impossible to retrieve the data in step (i) of the pipeline. As per the section 1, the ASPPL course is also open to healthcare students and society in general. That is, anyone, with or without professional registration, can take the course. With this premise in mind, the term "General Population" was assigned to the values absent in the CBO. For missing values for the region attribute, the term "Not Informed" was assigned. The missing values for other attributes were kept to preserve the originality and coherence of instances.

A series of data (pipeline step iii) was replaced and transformed through mappings on secondary sources based on specific attributes from the original dataset. Besides, new relevant attributes were added to the "asppl-dataset.csv" dataset. For the $\mathrm{CBO}$ attribute, the numeric code entered by each participant when enrolling in the course was converted into a text that describes the corresponding profession (17). New attributes were also created to store data referring to participants who registered more than one employment and health establishment to avoid loss of information. Furthermore, a new corresponding attribute was created for each employment record (based on $\mathrm{CBO}$ ) and establishment (based on CNES). According to Brazil's political-administrative and regional division (18) and the attribute referring to the participant's State (Federative Unit, UF), the region attribute was set up. It allows grouping participants into one of the five major regions of Brazil: North, Northeast, Midwest, Southeast, and South.

Conversely, the declared occupation attribute was removed to avoid redundancy and conflicts (pipeline step iv) between official data, registered in the Government database, and informal data. Such data can be consulted through $\mathrm{CBO}$, to which the course participant has also added. Further, to promote more transparency to this pre-processing data stage, we shall indicate the main weakness of the dataset: within the scope of "General Population," it is possible to create labels, such as "healthcare students" or other occupations. However, due to the technology's limitation, it is not mandatory to declare one's profession.

\section{DESCRIPTIVE ANALYSIS}

The data were analyzed for all 4,861 ASPPL course participants, as available in the "asppl-dataset.csv" dataset, with the aid of the Python programming language. In this pilot study, we mainly analyzed the profile, geographic location, and percentage of course completion of participants. Based on the latter, a total of $3,085(63.46 \%)$ people have completed the course, and $1,776(36.54 \%)$ are currently taking it. Of these, $229(4.71 \%)$ participants attended more than $50 \%$ of the program, and $1,547(31.83 \%)$ less than $50 \%$, as depicted in Figure 1A. Out of the group of participants who completed the course, $92.93 \%$ (2867) provided an evaluation, ascribing a score from 0 to 5 , related to the degree of satisfaction. Therefore, the arithmetic mean of the course evaluations is approximately 4.92 , with a 0.38 standard deviation and median equal to 5.0 .

Regarding participants' gender, a predominance of females was detected, with a total of 3,585 (73.8\%) women

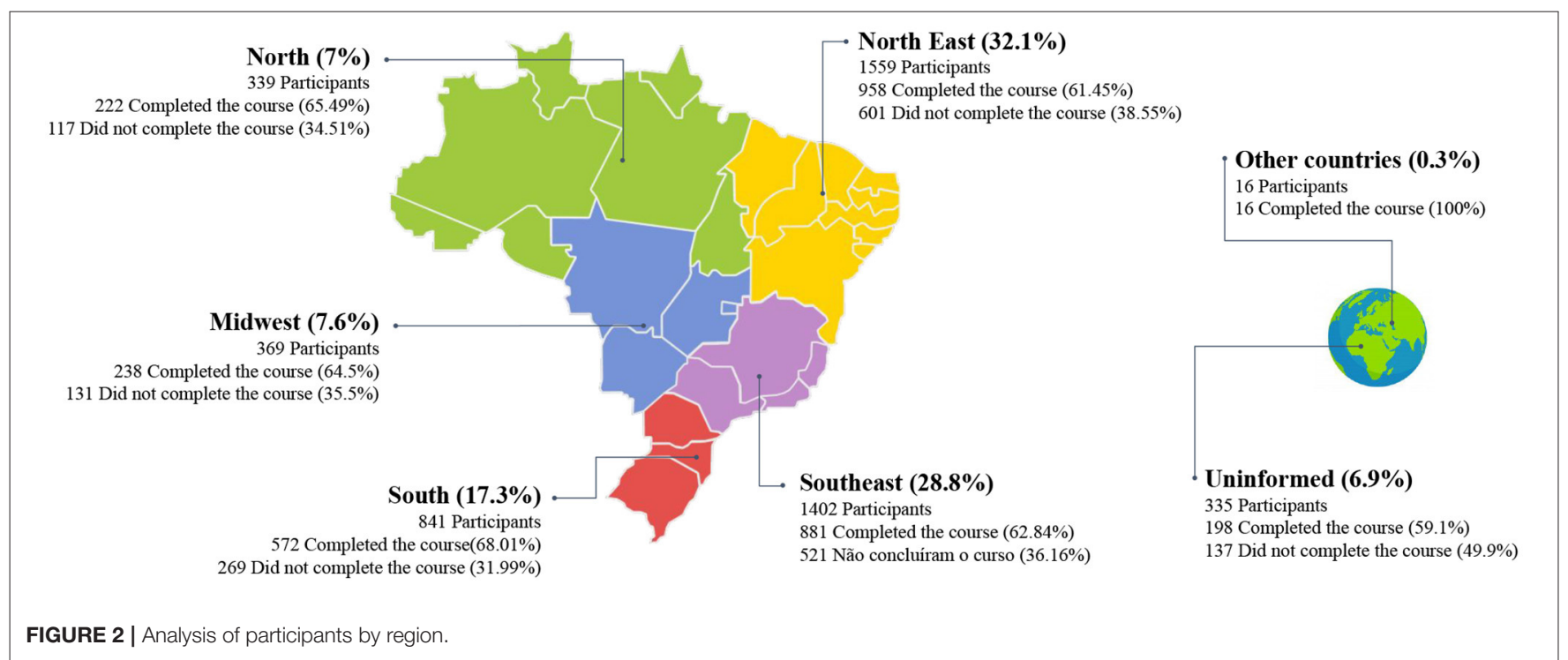


participants, as shown in Figure 1B. On the other hand, males are 1,266 (26\%) participants. Lastly, those who did not provide gender information and did not have their data retrieved, then called "Not informed," add up to $10(0.2 \%)$.

We nominally and quantitatively list the first 10 target items to synthesize the occupations and health establishments of the participants who most frequent the course. Figure 1C shows the most frequent occupations. Likewise, we present commercial establishments in Figure 1D. According to the guidelines established by the Ministry of Health, in Brazil, health establishments are categorized by level of care (primary, secondary, and tertiary). Hence, based on these data available in "asppl-dataset.csv", it is possible to group health establishments and analyze which level of care have trained professionals who meet the health care demands for dealing with STIs in the prison system.

For a clearer view of the geographic distribution of course participants, Figure 2 depicts a synthesis of participants by Brazilian region. The course attracted entries from participants from all five of Brazil's regions and their states. In addition to Brazil, it was identified that the ASPPL course had a total of $16(0.3 \%)$ participants residing in other countries. A total of $6.9 \%$ (335) of the participants did not inform their place of residence. As for Brazil, it can be observed that the Northeast is the region with the most participants, with a total of $1,559(32.1 \%)$, followed by the Southeast region, with 1,402 (28.8\%), South region, 841 (17.3\%), Midwest, 369 (7.6\%), and the North region, with 339 (7\%). Figure 2 reveals the number of participants who completed the course by region.

\section{REFERENCES}

1. Machado NO, Guimarães IS. A realidade do sistema prisional brasileiro e o princípio da dignidade da pessoa humana. Revista Eletrônica de Iniciação Cientifica. (2014) 5:566-81. Available online at: https://www.univali.br/ graduacao/direito-itajai/publicacoes/revista-de-iniciacao-cientifica-ricc/ edicoes/Lists/Artigos/Attachments/1008/Arquivo\%2030.pdf

2. Kallas M. A Falência do sistema prisional brasileiro. Direito em Movimento. (2019) 17:62-89. Available online at: http://emerj.com.br/ojs/seer/index.php/ direitoemmovimento/article/view/76/volume17_numero1_51.pdf

3. Machado FHB, Silva LS, Costa PAD, Rodrigues AS, Miranda ML. Health in prison: characterization and perception of inmates. Eur J Public Health. (2020) 9:30. doi: 10.1093/eurpub/ckaa166.793

4. Beato Filho C, Maria Silveira A, Mendonça Lopes Ribeiro L, Lacerda Siveira Rocha R, Lopes Souza R, Neiva e Oliveira V. Percepções Sociais sobre o Sistema Prisional Brasileiro:: um estudo quantitativo. Revista Brasileira de Execução Penal. (2020) 1:279-305. Available online at: http://rbepdepen. depen.gov.br/index.php/RBEP/article/view/139

5. Nascimento FDS. A Superlotação a crise do sistema prisional Brasileiro. Captura Criptica Direito Politica Atualidade. (2019) 8:114-25. Available online at: https://ojs.sites.ufsc.br/index.php/capturacriptica/article/view/3543

6. Quirino Filho J, Rolim Neto ML, do Nascimento VB. Incarcerated people in prisons: a public health priority in resource-poor settings. Forensic Sci Int Mind Law. (2020) 1:100007. doi: 10.1016/j.fsiml.2019. 100007

\section{DATA AVAILABILITY STATEMENT}

The original contributions presented in the study are included in the article/Supplementary Material, further inquiries can be directed to the corresponding author/s.

\section{AUTHOR CONTRIBUTIONS}

JV, EO, FF, IB, and MR structured and wrote the manuscript. JV, FF, IB, RV, and RS analyzed the data and contributed with descriptive analysis. SD-T, AD, AC-O, CT, and JH reviewed the manuscript. FF, IB, $\mathrm{RV}$, and RS organized the repository. All authors contributed to manuscript revision, read, and approved the submitted version.

\section{FUNDING}

This work was funded by Ministry of Health Brazil.

\section{ACKNOWLEDGMENTS}

We kindly thank the Laboratory for Technological Innovation in Health (LAIS) of the Federal University of Rio Grande do Norte (UFRN) and the Ministry of Health Brazil for supporting this research.

\section{SUPPLEMENTARY MATERIAL}

The Supplementary Material for this article can be found online at: https://www.frontiersin.org/articles/10.3389/fmed. 2021.742071/full\#supplementary-material

7. Lopes RL, Cavalcante A, Melo J, Cavalcante G, Oliveira A, Weslânnya P. Ocorrência de doenças infectocontagiosas em pessoas privadas de liberdade no sistema prisional. Interfaces Científicas Saúde e Ambiente. (2019) 7:53-60. doi: 10.17564/2316-3798.2019v7n2p\%p

8. Brasil. Levantamento Nacional de Informações Penitenciárias. Departamento Penitenciário Nacional (2021). Available online at: https://www.gov.br/depen/ pt-br/sisdepen/sisdepen

9. Batista MIHM, Paulino MR, Castro KS, Gueiros LAM, Leão JC, Carvalho AAT. Alta prevalência de sífilis em unidade prisional feminina do Nordeste Brasileiro. einstein. (2020) 18:1-6. doi: 10.31744/einstein_journal/2020 AO4978

10. Oliveira ESG, Valentim RAM, Trindade SD, Coutinho KD, Dias AP, Valentim JLRS, et al. Capítulo 9: A sífilis no sistema prisional Brasileiro, desafio para a saúde: uma análise baseada em dados. In: Gonçalves MNP, de Freitas IK, editors. Pesquisas Aplicadas No Panorama das Ciências da Saúde No Brasil. Rio de Janeiro (2021). p. $102-14$.

11. Cadamuro ACGA, Andrade RLP, Lopes LM, Neves LAS, Catoia EA, Monroe AA. Coordenação do cuidado às pessoas que vivem com HIV no sistema prisional. Acta Paulista de Enfermagem. (2020) 33:1-8. doi: 10.37689/acta-ape/2020AO02676

12. Alves KKAF, Borralho LM, Bernardino IM, Figueiredo TMRM. Análise temporal da incidência da tuberculose na populao privada de liberdade. Arch Health Investig. (2020) 9:655-60. doi: 10.21270/archi.v9i6. 4907 
13. Nascimento JR, Barbosa KMG, Vieira MCA. Abordando infecções sexualmente transmissíveis com mulheres reclusas: um relato de experiência. Extramuros Revista de Extensão da Univasf. (2019) 7:104-14. Available online at: https://www.periodicos.univasf.edu.br/index.php/extramuros/article/ view/1012

14. Benedetti MSG, Nogami ASA, Costa BB, Fonsêca HIF, Costa IS, Almeida IS, et al. Infecções sexualmente transmissíveis em mulheres privadas de liberdade em Roraima. Revista de Saúde Pública. (2020) 54:105. doi: 10.11606/s1518-8787.2020054002207

15. Brasil. Ambiente virtual de aprendizagem do SUS - AVASUS. Atenção à Saúde da Pessoa Privada de Liberdade (2021). Available online at: https://avasus. ufrn.br/local/avasplugin/cursos/curso.php?id=114

16. Brasil. CNES - Cadastro Nacional de Estabelecimentos de Saúde (2021). Available online at: http://cnes.datasus.gov.br/

17. Brasil. CBO - Classificação Brasileira de Ocupações (2021). Available online at: http://www.mtecbo.gov.br/cbosite/pages/home.jsf

18. EducaIBGE. Divisão Politico-Administrativa e Regional (2021). Available online at: https://educa.ibge.gov.br/jovens/conheca-o-brasil/territorio/ 18310-divisao-politico-administrativa-e-regional.html
Conflict of Interest: The authors declare that the research was conducted in the absence of any commercial or financial relationships that could be construed as a potential conflict of interest.

Publisher's Note: All claims expressed in this article are solely those of the authors and do not necessarily represent those of their affiliated organizations, or those of the publisher, the editors and the reviewers. Any product that may be evaluated in this article, or claim that may be made by its manufacturer, is not guaranteed or endorsed by the publisher.

Copyright (c) 2021 Valentim, Oliveira, Valentim, Dias-Trindade, Dias, CunhaOliveira, Barbalho, Fernandes, Silva, Romão, Teixeira and Henriques. This is an open-access article distributed under the terms of the Creative Commons Attribution License (CC BY). The use, distribution or reproduction in other forums is permitted, provided the original author(s) and the copyright owner(s) are credited and that the original publication in this journal is cited, in accordance with accepted academic practice. No use, distribution or reproduction is permitted which does not comply with these terms. 